\title{
Antibacterial, Antioxidant and Anti-Inflammatory Potential of the Different Extracts of Holoptelia Integrifolia
}

\author{
T. Mohammad Munawar, D. Muralidhara Rao, P. Subramanyam
}

\begin{abstract}
Medicinal plants are play significant impact in the personal medicine for most of the people all over the world as an alternative live saving medicines and most of their medicinal properties are well known for anticancer activity. The different extracts of Holoptelea integrifolia (H.integrifolia) leaves, stem bark and fruits were studied as a potent natural source of antimicrobial, antioxidant and wound healing potential. This work was carried out to evaluate antimicrobial, antioxidant and anti-inflammatory activity of different extracts of H.integrifolia. The antimicrobial activity of the H.integrifolia ethanolic extract was studied against five fungal and bacterial strains by utilizing the agar well diffusion method and MIC. Among several strain, the ethanolic extract of fruit has shown higher antimicrobial inhibition zone as $9.25-16 \mathrm{~mm}$ compare to other two extracts of stem and leaves as 10-13.25 mm and 6-10.2 $\mathrm{mm}$ respectively. The antioxidant activities for different extract were also determined by DPPH free radical assay, Hydroxyl Radical Scavenging and Nitric Oxide Radical Scavenging Activity method. The anti-inflammatory activity also estimated basedon formalin induced paw edema method on Wistar albino rats. The different extracts of leaves, stem bark and fruit parts of Holoptelea integrifolia were estimated for in vivo anti-inflammatory activity against the animal model of female Wistar albino rats. The results of anti-inflammatory activity revealed that the Ethanol extracts showed vital and dose-dependent anti-inflammatory effects. Our findings revealed that aerial parts of $H$.integrifolia contais potential antimicrobial, antioxidant and anti-inflammatory compounds, which expose the medicinal potential of the selected plant could be a significant drug candidates against microbial, oxidative and inflammation-related pathological processes as a future alternative medicine.
\end{abstract}

Keywords: Holoptelea integrifolia, Microbial inhibition concentration, DPPH, Hydroxyl Radical Scavenging, Nitric Oxide Radical Scavenging, Anti-inflammatory.

\section{INTRODUCTION}

Medicinal plants are getting used for treating diseases based on the bacterial and fungal origin and best

Revised Manuscript Received on December 30, 2019.

* Correspondence Author

Dr.T.Mohammad Munawar*, Department of Biological and Chemical Engineering, Mekelle Institute of Technology (MIT), Mekelle University1632, Ethiopia., E-mail: munna686@gmail.com.

Dr.D.Muralidhara Rao, Department of Biotechnology, Sree Kroshnadevarya University, Anantapuramu-515003, Andhra Pradesh, India., E-mail: muralidhararao@yahoo.com

Dr. P.Subramanyam, Department of Botany, Loyola Degree College, Pulivendula-516390, Andhra Pradesh, India.. E-mail: subramanyampaluru@gmail.com

(C) The Authors. Published by Blue Eyes Intelligence Engineering and Sciences Publication (BEIESP). This is an open access article under the CC BY-NC-ND license (http://creativecommons.org/licenses/by-nc-nd/4.0/) results are obtained with a number of them. However, the major scientific investigation and data of the therapeutical impact of these plants are very limited [1]. In recent years the scientific community understand the mechanism of free radical scavenging activity which play critical role of anti-inflammatory, digestive, antinecrotic, neuroprotective and hepatoprotective drugs [2,3]. Inflammation and oxidative stress play a vital role in various immunological diseases as primary immune response when ever allergens, injuries, cuts, bacterial and fungal infections raised and also at other harmful stimulus [4]. H.integrifolia is a medium greeny wigroius tree of $15-25 \mathrm{~m}$ in height and whitish or yellowish grey and cut freshly posses' pleasant smell [5]. H.integrifolia is important medicinal plant, is the rich supply of different types of important compounds such as Holoptelin- $A$ Holoptelin-B, Friedlin 2-aminonaphthoquinone, $\beta$-sitosterol, stigmasterol and hederagenin where reported from heart wood and bark, while hexacosanol octacosanol and $\alpha$-amyrin were reported in leaves [6]. The current work was performed to evaluate the antimicrobial, antioxidant and anti-inflammatory activity of different extracts for leaves, stem and fruits of Holoptelea integrifolia.

\section{MATERIAL AND METHODS}

\section{A. Plant material}

The aerial part of fresh stem bark, leaves and fruit of Holoptelia integrifolia were collected from the Sheshachalam hills, Andhra Pradesh India. Plant species were authenticated by Prof. C. Sudhakar, S.K University, Anantapuramu, India and voucher specimens, were deposited at the herbarium, Department of Botany, Loyola College (YSRR) Pulivendula. The respective materials were washed with running tap water by 2-3 times thoroughly. Then the materials were air and shadow dried and mechanically crushed into coarse powder of $40 \mu \mathrm{m}$ sizes by using mixer grinder. Powders were stored separately in air all around tight little covers.

\section{B. Chemicals and Reagents}

The entire chemicals were purchased from Tarun Scientifics (Kadapa District, A.P State, India). All the chemical reagents used were of analytical grade.

\section{Microorganisms and animals}

Healthy adult Albino wistar rats were about 125-250 g and Swiss albino mice were about 20-25 g were collected from the animal facilities of the Rural College of Pharmacy, Devanahalli, Karnataka, India.

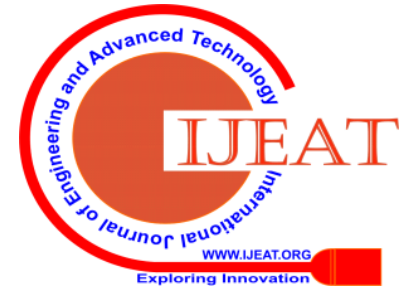


were kept in well ventilated house cage and animals had 12 hour day and night schedule with temperature between $23 \pm 2{ }^{\circ} \mathrm{C}$ and relative humidity $75 \%$. During the experimental course period, the animals were kept in large hygienic spacious cages and it was allowed for free movement according standard laboratory cube pellets and provided drinking water facilites. The work was carried out after getting clearance of ethical committee from the institutional subtilise, Pseudomonas aeruginosa Micrococcus luteus, Eschericia coli and Proteus vulgaris) and fungal cultures (Asperigillus niger, Aspergillus flavus, Tricoderma vibriae, Penicillium rubrum and Chaetomium globosum ) were got from Microbial collection center for Type Culture(MTCC), Chandigarh, India. They cultures were grown at $4^{\circ} \mathrm{C}$ on nutrient agar medium.

\section{Preparation of extracts}

Extracts were prepared in order to study their antioxidant activity. Ethanol, acetone and aqueous extracts of each of the leaves, stem bark and fruit were prepared by soaking the powders in the three solvents for $72 \mathrm{~h}$ and the mixture was mixed with a sterile glass rod for every 24h., then the extracts were filtered using a Buckner funnel and Whatman No.1filter paper and concentrated by vacuum drying.

\section{E. Pharmacological evaluation}

\section{Antioxidant activity}

The DPPH radical scavenging activity of different solvent extracts of leaves, stem bark and fruit of Holoptelea integrifolia was assessed according to the previous method [7]. $1 \mathrm{ml}$ of freshly prepared methanol solution of DPPH of 1 $\mathrm{mM}$ was mixed with different solvent extracts at different concentrations as $10-100 \mu \mathrm{g} / \mathrm{ml}$. The reaction mixture was rattled and incubated at $37{ }^{\circ} \mathrm{C}$ for $30 \mathrm{~min}$ in dark place and absorbance was measured at $517 \mathrm{~nm}$. In this activity, ascorbic acid considered as control and methanol as blank was also carried out simultaneously. The antioxidant BHT was used as a positive control in all assays. The inhibition of RSA was determined by the given equation.

$\%$ RSA $=\left(\left[\mathrm{A}_{0}-\mathrm{A}_{\mathrm{S}}\right]\right) / \mathrm{A}_{0} \times 100$

Where $A_{0}$ and $A_{S}$ are the absorbance of the control (containing all reagents, except the test compound) and test compound respectively.

\subsection{Hydroxyl radical scavenging activity (HRSA)}

HRS activity of different extracts of leaves, stem bark and fruits of Holoptelea integrifolia was evaluated as described previously [8] with small changes. $100 \mu \mathrm{l}$ of different concentrations of extracts was dissolved in buffer as 10-100 $\mu \mathrm{g} / \mathrm{ml}$ at $0.6 \mathrm{ml}$ of $\mathrm{PO}_{4}$ buffer at $\mathrm{pH} 7.4$ along with $10 \mathrm{mM}$ deoxyribose and $170 \mathrm{mM}$ EDTA and the reaction was carried out by adding $100 \mu \mathrm{l}$ of ascorbic acid $(2 \mathrm{mM})$ and $100 \mu \mathrm{l}$ of $10 \mathrm{mM} \mathrm{H}_{2} \mathrm{O}_{2}$. The reaction was stopped by the addition of 1 $\mathrm{ml}$ of $1 \%$ was heated at boiling water bath for $5 \mathrm{~min}$ after the incubation period of $20 \mathrm{~min}$ at $80-90{ }^{\circ} \mathrm{C}$. The quantity of pink-colored chromogen was recorded at $532 \mathrm{~nm}$ and ascorbic acid as a control.

\subsection{Nitric Oxide Radical Scavenging Activity}

NOR Scavenging Activity of different extracts of leaves, stem bark and fruit for Holoptelea integrifolia was evaluated system [9]. Sodium nitroprusside ( $1 \mathrm{ml}$ of $10 \mathrm{mM})$ were mixed animal ethical committee. The Bacterial cultures (Bacillus

\subsection{DPPH free radical scavenging activity}

with 1ml of HAEF of different concentration (50-250 $\mu \mathrm{g} / \mathrm{mL}$ ) in phosphate buffer ( $\mathrm{pH} 7.4)$. The mixture was incubated at $25^{\circ} \mathrm{C}$ for $150 \mathrm{~min}$. $1 \mathrm{ml}$ of Griess's reagent was added to $1 \mathrm{ml}$ of the incubated solution. Absorbance was recorded at $546 \mathrm{~nm}$. Ascorbic acid was utilized as the reference material. All tests were performed in triplicate and the results averaged. The \% inhibition of OD was determined by the given formula.

$\%$ inhibition = Abs control - Abs sample/Abs control $\times 100 \%$

(2)

\section{Antimicrobial activity}

\subsection{Agar-well diffusion assay}

Clinical Pathogenic bacteria such as Bacillus subtilis, Pseudomonas aeruginosa Micrococcus luteus , Eschericia coli and Proteus vulgaris and fungal cultures (Asperigillus niger, Aspergillus flavus, Tricoderma vibriae, Penicillium rubrum and Chaetomium globosum) were procurred from MTCC, Chandigarh, India were used to perform the antimicrobial activity and antifungal by means of agar well-diffusion and MIC assay. All pure cultured bacteria were sub-cultured in the nutrient broth and incubated for $24 \mathrm{~h}$ at $30{ }^{\circ} \mathrm{C}$ in the rotatory shaker. The liquid bacterial culture was wipped on the Mueller-Hinton agar plates and $8 \mathrm{~mm}$ of hole was bored at the centre of plates [10]. The holes were filled with $100 \mu$ l ethanolic solvent extracts of leaves, stem bark and fruit of Holoptelea integrifolia were tested in a concentration of $50 \mathrm{mg} / 100 \mu \mathrm{l}$ and standard antibiotic (gentamycin) of 3 incubated at $37^{\circ} \mathrm{C}$ for bacterial strains about 24-48 h and standard antibiotic (Nystatin) for fungal strains about 3-5 days. The measurement of the inhibition zone diameter around the well were determined by the antibacterial and antifungal activities.

\section{Anti - inflammatory Activity}

\subsection{Acute Anti inflammatory Activity \\ 3.1.1 Formalin-induced Paw Oedema in mice}

Acute inflammation was induced by injecting $0.1 \mathrm{ml}$ of $1 \%$ formalin $(0.1 \mathrm{ml}$ of $1 \%$ suspension in $0.9 \%$ saline) suspension in sub-plantar region and paw volume was measured 0,1,2,3,4 and 5 hours by using of Plethysmometer. All the treatment compounds were given $30 \mathrm{~min}$, prior to formalin. Acute inflammation was induced in the right hind paw [11]. After injecting formalin, the first reading was taken at zero hr. and the protocol was repeated at first, second, third, four and fifth hours after formalin injection. The difference between $0 \mathrm{hr}$ reading and one of the subsequent readings provide the actual oedema volume at the time [12]. The mean paw volume at different times was calculated and compared with the control and the percentage inhibition was determined with the help of the equation

Percent inhibition $=\left[\left(\mathrm{Vt}-\mathrm{V}_{0}\right)\right.$ control $-\left(\mathrm{Vt}-\mathrm{V}_{0}\right)$ treated $]$ $/\left(\mathrm{Vt}-\mathrm{V}_{0}\right)$ control $\times 100$

Group-I: Animlas injected distilled water and considered as control.

Group-II: Animals injected with concentration of $10 \mathrm{mg} / \mathrm{kg}$ of Diclofenac sodium i.p. and served as standard.

Group- III to VIII: Animals injected with concentration of $300 \mathrm{mg} / \mathrm{kg}$ of acetone, ethanol and water plants extracts.

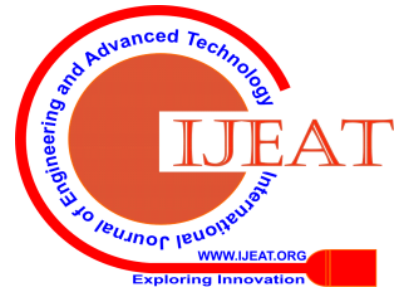




\subsection{Chronic Anti inflammatory Activity \\ 3.2.1 Formalin Induced Paw Oedema}

Albino wistar female rats weighing $170-250 \mathrm{mg} / \mathrm{kg}$ were Albino wistar female rats weighing $170-250 \mathrm{mg} / \mathrm{kg}$ were separated into eleven groups and each group contains six rats. Before the starting of the experiment, all the animals were fasted for 18 hrs and water was given ad libitum [18]. In animals of all the groups chronic inflammation was produced by sub plantar injection of $20 \mu \mathrm{L}$ of freshly prepared $2 \%$ suspension of formalin in normal saline in right hind paw of rat was used as the oedematogenic agent. Animals were treated with drugs for six consecutive days. The paw volume was measured using a plethysmometer before and 6 days after formalin tested in each group. The paw volume increase and percent of inhibition was calculated and compared with the control and the percentage inhibition was determined by using the equation

Percent inhibition $=\left[\left(\mathrm{Vt}-\mathrm{V}_{0}\right)\right.$ control $-\left(\mathrm{Vt}-\mathrm{V}_{0}\right)$ treated] $/(\mathrm{Vt}-\mathrm{V} 0)$ control $\times 100$

(4)

Group-I: Animlas injected distilled water and considered as control.

Group-II: Animals injected with concentration of $100 \mathrm{mg} / \mathrm{kg}$ of Diclofenac sodium i.p. and served as standard.

Group- III to VIII: Animals injected with concentration of $300 \mathrm{mg} / \mathrm{kg}$ of acetone, ethanol and water plants extracts.

\section{Statistical analysis}

All experiments were performed in triplicates and results were presented at the mean. Statistical analysis was conducted with multiple variance analysis (two-way ANOVA) with the Tukey's test by comparing every extracts with BHT for the Dose-response relationship.

\section{RESULTS AND DISCUSSION}

\section{A. Preliminary phytochemical screening}

Preliminary phytochemical screening of the leaves, stem bark and fruits of Holoptelea integrifolia investigations contains; unsaturated sterols or triterpenoides, Flavonoids, Carbohydrates or glycosides, Proteins and/ or amino acids, Tannins and Coumarin [14].

B. Antimicrobial activity
The results were obtained and compared with the scale developed by Arora and Bhardwaj [15]. The results of zone of inhibition and drug sensitivity were described as below.

Table I: Zone of Inhibition and drug sensitivity relationship

\begin{tabular}{|lcc|}
\hline S. No. & Zone of Inhibition (m.m.) & Drug Sensitivity \\
\hline 1. & N.I. (below 6) & Insensitive \\
\hline 2. & $6<9$ & Less sensitive \\
\hline 3. & $9<12$ & Moderate sensitive \\
\hline 4. & $>12$ & Highly sensitive \\
\hline
\end{tabular}

The antibacterial and antifungal activities of leaves, stem and fruit of Holoptelea integrifolia ethanolic extracts were determined by well-diffusion method. All the investigated Holoptelea integrifolia extracts showed antibacterial and antifungal activities (Tables I and II).

The results of leaves extract of Holoptelea integrifolia revealed significant antibacterial activity against Bacillus subtilis $(7.00 \pm 0.25 \mathrm{~mm})$, Pseudomonas aeruginosa (8.25 \pm $0.25 \mathrm{~mm}$ ) Micrococcus luteus (10.2 $\pm 0.10 \mathrm{~mm})$, Escherichia

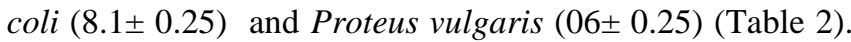
The stem extract of Holoptelea integrifolia revealed significant antibacterial activity against Bacillus subtilis (11.2 $\pm 0.25 \mathrm{~mm})$, Pseudomonas aeruginosa (12.25 \pm 0.25 $\mathrm{mm})$ Micrococcus luteus (13.25 $\pm 0.25 \mathrm{~mm})$, Escherichia coli $(12 \pm 0.25)$ and Proteus vulgaris $(10 \pm 0.25)$. The antibacterial activity of leaves extract of Holoptelea integrifolia was obtained against Bacillus subtilis $(9.1 \pm 0.25 \mathrm{~mm})$, Pseudomonas aeruginosa $(9.25 \pm 0.25 \mathrm{~mm})$ Micrococcus luteus $(16 \pm 0.25 \mathrm{~mm})$, Escherichia coli $(09 \pm 0.25)$ and Proteus vulgaris $(08 \pm 0.25)$. The highest antibacterial activity obtained by Holoptelea integrifolia was $12.25 \pm 0.25$ (stem extract) against Pseudomonas aeruginosa, 11.2 0.25 (stem extract) against Bacillus subtilis, $16 \pm 0.25$ (fruit extract) against Micrococcus luteus, $12 \pm 0.25$ (stem extract) against Escherichia coli and $10 \pm 0.25$ (stem extract) against Proteus vulgaris (Table II).

Based on antifungal activity of the leaf, stem and fruit extracts of Holoptelea integrifolia reveals that the highest activity; $12 \pm 0.25 \mathrm{~mm}, 13.1 \pm 2.25 \mathrm{~mm}, 8.5 \pm 0.25$ (stem extract) was obtained by Holoptelea integrifolia against Asperigillus niger, Tricoderma vibriae and Chaetomium globosum species respectively (Table II).

Table- II: Zone of inhibition of ethanolic extract of leaves, stem and fruit of Holoptelea integrifolia

\begin{tabular}{|c|c|c|c|c|c|}
\hline S.No & Bacteria & Leaves extract & Stem extract & Fruit Extract & $\begin{array}{c}\text { Standard } \\
\text { Antibiotic } \\
\end{array}$ \\
\hline 1. & Pseudomonas aeruginosa MTCC1688 & $8.25 \pm 0.25$ & $12.25 \pm 0.25$ & $9.25 \pm 0.25$ & $11.1 \pm 0.25$ \\
\hline 2. & Bacillus subtilus MTCC 121 & $7.00 \pm 0.25$ & $11.2 \pm 0.25$ & $9.1 \pm 0.25$ & $13.4 \pm 2.25$ \\
\hline 3. & Micrococcus luteus MTCC 1541 & $10.2 \pm 0.10$ & $13.25 \pm 0.25$ & $16 \pm 0.25$ & $20.1 \pm 0.25$ \\
\hline 4. & Eschericia coli MTCC1687 & $8.1 \pm 0.25$ & $12 \pm 0.25$ & $09 \pm 0.25$ & $17.2 \pm 1.25$ \\
\hline 5. & $\begin{array}{l}\text { Proteus vulgaris MTCC } 1771 \\
\text { Fungi }\end{array}$ & $06 \pm 0.25$ & $10 \pm 0.25$ & $08 \pm 0.25$ & $12.1 \pm 2.25$ \\
\hline 1. & Asperigillus niger MTCC 1344 & $07 \pm 0.25$ & $12 \pm 0.25$ & $10 \pm 0.25$ & $13.4 \pm 1.25$ \\
\hline 2. & Asperigillus flavus MTCC 1444 & ND & ND & ND & $14.1 \pm 2.25$ \\
\hline 3. & Tricoderma vibriae MTCC 1564 & ND & $13.1 \pm 2.25$ & $12 \pm 0.25$ & $16.1 \pm 0.25$ \\
\hline 4. & Pencillium rubrum MTCC 214 & ND & ND & ND & $16.2 \pm 1.25$ \\
\hline 5. & Chaetomium globosum MTCC 344 & $2.2 \pm 0.25$ & $8.5 \pm 0.25$ & $7.0 \pm 0.25$ & $12.1 \pm 0.25$ \\
\hline
\end{tabular}


ND, not determined. These are the mean of three determinations.

\section{Antioxidant activity}

3.2.1. Antioxidant activity (DPPH free radical antioxidant activity of different plant, algal and fungal scavenging) extracts [16].

In several diseases like AIDS, Neurodegenerative diseases and cancer, the free radicals are responsible for causing those diseases and scavenging activity of antioxidants is responsible for the control of those diseases. The most commonly and sensitive method used for screening of antioxidants was DPPH assay and it determine the

Table III: DPPH free radical scavenging of different extracts of leaves and bark of H.integrifolia

\begin{tabular}{|c|c|c|c|c|c|}
\hline \multirow{2}{*}{ Test Compounds } & \multicolumn{5}{|c|}{$\%$ Inhibition for Absorbance (Mean \pm SEM) } \\
\hline & $50 \mu \mathrm{g} / \mathrm{ml}$ & $100 \mu \mathrm{g} / \mathrm{ml}$ & $150 \mu \mathrm{g} / \mathrm{ml}$ & $200 \mu \mathrm{g} / \mathrm{ml}$ & $250 \mu \mathrm{g} / \mathrm{ml}$ \\
\hline Ascorbic acid & $\begin{array}{c}1.102 \pm 0.008 \\
(34.71 \%)\end{array}$ & $\begin{array}{c}0.517 \pm 0.002 \\
(69.54 \%)\end{array}$ & $\begin{array}{c}0.199 \pm 0.002 \\
-84.46 \%\end{array}$ & $\begin{array}{c}0.137 \pm 0.002 \\
(91.89 \%)\end{array}$ & $\begin{array}{c}0.116 \pm 0.001 \\
(93.14 \%)\end{array}$ \\
\hline HI -LV-ETH & $\begin{array}{c}1.320 \pm 0.005 \\
(27.85 \%)\end{array}$ & $\begin{array}{c}0.835 \pm 0.002 \\
\quad(50.62 \%)\end{array}$ & $0.551 \pm 0.004(67.41 \%)$ & $\begin{array}{l}0.221 \pm 0.002 \\
\quad(86.93 \%)\end{array}$ & $\begin{array}{c}0.155 \pm 0.002 \\
(90.83 \%)\end{array}$ \\
\hline HI -LV-ACET & $\begin{array}{c}1.243 \pm 0.008 \\
(27.08 \%)\end{array}$ & $\begin{array}{c}0.972 \pm 0.005 \\
\quad(42.63 \%)\end{array}$ & $0.645 \pm 0.002(61.85 \%)$ & $\begin{array}{l}0.288 \pm 0.004 \\
\quad(82.96 \%)\end{array}$ & $\begin{array}{c}0.191 \pm 0.001 \\
-88.70 \%\end{array}$ \\
\hline HI -LV-WATE & $\begin{array}{c}1.300 \pm 0.005 \\
(23.12 \%)\end{array}$ & $\begin{array}{c}0.968 \pm 0.004 \\
-42.81 \%\end{array}$ & $0.712 \pm 0.004(57.95 \%)$ & $\begin{array}{l}0.438 \pm 0.001 \\
\quad(74.09 \%)\end{array}$ & $\begin{array}{c}0.207 \pm 0.001 \\
-87.69 \%\end{array}$ \\
\hline HI- BRK-ETH & $\begin{array}{c}1.328 \pm 0.001 \\
-21.46 \%\end{array}$ & $\begin{array}{c}1.117 \pm 0.044 \\
(33.94 \%)\end{array}$ & $0.788 \pm 0.004(53.40 \%)$ & $\begin{array}{c}0.558 \pm 0.003 \\
\quad(67.12 \%)\end{array}$ & $\begin{array}{c}0.301 \pm 0.006 \\
(82.19 \%)\end{array}$ \\
\hline HI -BRK-ACET & $\begin{array}{c}1.275 \pm 0.002 \\
(24.60 \%)\end{array}$ & $\begin{array}{c}1.073 \pm 0.030 \\
(36.60 \%)\end{array}$ & $0.915 \pm 0.002(45.89 \%)$ & $\begin{array}{c}0.685 \pm 0.002 \\
\quad(59.49 \%)\end{array}$ & $\begin{array}{c}0.515 \pm 0.002 \\
(69.54 \%)\end{array}$ \\
\hline HI -BRK- WATE & $\begin{array}{c}1.255 \pm 0.002 \\
(25.78 \%)\end{array}$ & $\begin{array}{c}0.865 \pm 0.002 \\
(48.84 \%)\end{array}$ & $0.458 \pm 0.001(72.91 \%)$ & $\begin{array}{c}0.209 \pm 0.001 \\
(87.69 \%)\end{array}$ & $\begin{array}{c}0.149 \pm 0.002 \\
(91.42 \%)\end{array}$ \\
\hline
\end{tabular}

HI :Holoptelia integrifolia , LV :Leaves, ETH: ethanol extract, ACE: acetone, WATE: water extract, BRK: bark

The ethanol, Acetone and water extract of leaf and Bark of Holoptelia integrifolia showed DPPH radical scavenging activity depends on the concentration manner (Table III). The DPPH scavenging activity was found to be $90.83 \%, 88.70 \%$, $87.69 \% \%$ and $93.14 \%$ at $250 \mu \mathrm{g} / \mathrm{ml}$ for ethanol, acetone, water extract and Vitamin $\mathrm{C}$ for leaves of Holoptelia integrifolia (Table III). The DPPH scavenging activity was found to be $82.19 \% \%, 69.54 \%, 91.42 \%$ and $93.14 \%$ at 250 $\mu \mathrm{g} / \mathrm{ml}$ for ethanol, acetone and water extract and Vitamin C for bark of Holoptelia integrifolia. The maximum scavenging activity (90.83\% and $91.42 \%)$ was provided by ethanol extract of leaves and water extract of bark for Holoptelia integrifolia.

\section{Antioxidant activity (Hydroxyl Radical Scavenging)}

The ethanol, Acetone and water extract of leaf and Bark of Holoptelia integrifolia showed Hydroxyl Radical Scavenging in a concentration- dependent manner (Table IV). The Hydroxyl Radical Scavenging was found to be $74.43 \%, 65.66 \%, 70.42 \%$ and $80.20 \%$ at $250 \mu \mathrm{g} / \mathrm{ml}$ for ethanol, acetone and water extract and Vitamin $\mathrm{C}$ for leaves of Holoptelia integrifolia (Table IV). The DPPH scavenging activity was found to be $66.16 \%, 69.42 \%, 72.68 \%$ and $80.20 \%$ at $250 \mu \mathrm{g} / \mathrm{ml}$ for ethanol, acetone and water extract and Vitamin $\mathrm{C}$ for bark of Holoptelia integrifolia. The maximum scavenging activity $(74.43 \%$ and $72.68 \%)$ was provided by ethanolic extract of leaves and water extract of bark for Holoptelia integrifolia.

Table IV: Hydroxyl Radical scavenging of different extracts of leaves and bark of Holoptelea integrifoli

\begin{tabular}{|l|c|c|c|c|c|}
\hline \multirow{2}{*}{ Test Compounds } & \multicolumn{5}{|c|}{$\%$ Inhibition for Concentration (Mean \pm SEM) } \\
\cline { 2 - 6 } & $\mathbf{5 0} \mathbf{\mu g} / \mathbf{m l}$ & $\mathbf{1 0 0} \mathbf{\mu g} / \mathbf{m l}$ & $\mathbf{1 5 0} \mathbf{\mu g} / \mathbf{m l}$ & $\mathbf{2 0 0} \mathbf{\mu g} / \mathbf{m l}$ \\
\hline Ascorbic acid & $\begin{array}{c}0.209 \pm 0.002 \\
(49.37 \%)\end{array}$ & $\begin{array}{c}0.149 \pm 0.002 \\
(62.65 \%)\end{array}$ & $\begin{array}{c}0.113 \pm 0.002 \\
(71.67 \%)\end{array}$ & $\begin{array}{c}0.094 \pm 0.001 \\
(76.44 \%)\end{array}$ & $\begin{array}{c}0.078 \pm 0.001 \\
(80.20 \%)\end{array}$ \\
\hline
\end{tabular}




\begin{tabular}{|l|c|c|c|c|c|}
\hline HI -LF-ETH & $0.274 \pm 0.001$ & $0.215 \pm 0.002$ & $0.176 \pm 0.002$ & $0.122 \pm 0.003$ & $0.102 \pm 0.002$ \\
& $(31.57 \%)$ & $(46.11 \%)$ & $(55.88 \%)$ & $(69.42 \%)$ & $(74.43 \%)$ \\
\hline HI -LF-ACET & $0.294 \pm 0.002$ & $0.233 \pm 0.002$ & $0.186 \pm 0.001$ & $0.153 \pm 0.002$ & $0.137 \pm 0.001$ \\
& $(27.06 \%)$ & $(41.60 \%)$ & $(54.13 \%)$ & $(61.65 \%)$ & $(65.66 \%)$ \\
\hline HI -LF-WATE & $0.266 \pm 0.004$ & $0.218 \pm 0.002$ & $0.172 \pm 0.001$ & $0.134 \pm 0.002$ & $0.117 \pm 0.002$ \\
& $(34.08 \%)$ & $(45.11 \%)$ & $(56.89 \%)$ & $(66.41 \%)$ & $(70.42 \%)$ \\
\hline HI- BRK-ETH & $0.256 \pm 0.004$ & $0.201 \pm 0.003$ & $0.179 \pm 0.002$ & $0.158 \pm 0.002$ & $0.133 \pm 0.001$ \\
& $(35.83 \%)$ & $(49.62 \%)$ & $(56.14 \%)$ & $(60.40 \%)$ & $(66.16 \%)$ \\
\hline HI -BRK-ACET & $0.271 \pm 0.001$ & $0.224 \pm 0.001$ & $0.163 \pm 0.002$ & $0.141 \pm 0.001$ & $0.121 \pm 0.002$ \\
& $(32.08 \%)$ & $(43.10 \%)$ & $(59.14 \%)$ & $(64.66 \%)$ & $(69.42 \%)$ \\
\hline HI -BRK- WATE & $0.248 \pm 0.002$ & $0.193 \pm 0.003$ & $0.162 \pm 0.002$ & $0.130 \pm 0.001$ & $0.108 \pm 0.002$ \\
& $(37.84 \%)$ & $(50.62 \%)$ & $(59.14 \%)$ & $(67.41 \%)$ & $(72.68 \%)$ \\
\hline
\end{tabular}

HI- Holoptelia integrifolia , LV- Leaves , ETH- ethanol extract, Ace- acetone, WATE- water extract, BRK- bark

2. Antioxidant activity (Nitric Oxide Radical Scavenging) The ethanol, Acetone and water extract of leaf and Bark of Holoptelia integrifolia showed Nitric Oxide Radical Scavenging activity in a concentration- dependent manner (Table V). The Nitric Oxide Radical Scavenging was found to be $73.39 \%, 67.57 \%, 70.76 \%$ and $80.11 \%$ at $250 \mu \mathrm{g} / \mathrm{ml}$ for ethanol, acetone and water extract and Vitamin $\mathrm{C}$ for leaves of Holoptelia integrifolia (Table V). The DPPH scavenging activity was found to be $64.91 \% \%, 70.76 \%, 72.80 \%$ and $80.11 \%$ at $250 \mu \mathrm{g} / \mathrm{ml}$ for ethanol, acetone and water extract and Vitamin $\mathrm{C}$ for bark of Holoptelia integrifolia. The maximum scavenging activity (73.39\% and $72.80 \%)$ was provided by ethanolic extract of leaves and water extract of bark for Holoptelia integrifolia.

Table V: Nitric Oxide scavenging of different extracts of leaves and Bark of Holoptelea integrifolia

\begin{tabular}{|c|c|c|c|c|c|}
\hline \multirow{2}{*}{ Test Compounds } & \multicolumn{5}{|c|}{$\%$ Inhibition for Concentration (Mean \pm SEM) } \\
\hline & $50 \mu \mathrm{g} / \mathrm{ml}$ & $100 \mu \mathrm{g} / \mathrm{ml}$ & $150 \mu \mathrm{g} / \mathrm{ml}$ & $200 \mu \mathrm{g} / \mathrm{ml}$ & $250 \mu \mathrm{g} / \mathrm{ml}$ \\
\hline Ascorbic acid & $\begin{array}{c}0.158 \pm 0.004 \\
(53.80 \%) \\
\end{array}$ & $\begin{array}{c}0.135 \pm 0.002 \\
(60.52 \%)\end{array}$ & $\begin{array}{c}0.115 \pm 0.002 \\
(66.37 \%)\end{array}$ & $\begin{array}{c}0.100 \pm 0.002 \\
(70.76 \%)\end{array}$ & $\begin{array}{c}0.068 \pm 0.001 \\
(80.11 \%) \\
\end{array}$ \\
\hline HI -LF-ETH & $\begin{array}{c}0.195 \pm 0.002 \\
(42.98 \%)\end{array}$ & $\begin{array}{c}0.160 \pm 0.002 \\
(53.21 \%)\end{array}$ & $\begin{array}{c}0.136 \pm 0.004 \\
(60.23 \%)\end{array}$ & $\begin{array}{c}0.115 \pm 0.002 \\
(66.37 \%)\end{array}$ & $\begin{array}{c}0.091 \pm 0.016 \\
(73.39 \%)\end{array}$ \\
\hline HI -LF-ACET & $\begin{array}{c}0.193 \pm 0.001 \\
(43.56 \%)\end{array}$ & $\begin{array}{c}0.168 \pm 0.001 \\
(50.87 \%)\end{array}$ & $\begin{array}{c}0.150 \pm 0.002 \\
(56.14 \%)\end{array}$ & $\begin{array}{c}0.135 \pm 0.002 \\
(60.52 \%)\end{array}$ & $\begin{array}{c}0.111 \pm 0.004 \\
(67.57 \%)\end{array}$ \\
\hline HI -LF-WATE & $\begin{array}{c}0.181 \pm 0.001 \\
(40.35 \%)\end{array}$ & $\begin{array}{c}0.158 \pm 0.001 \\
(53.80 \%) \\
\end{array}$ & $\begin{array}{c}0.138 \pm 0.004 \\
(59.64)\end{array}$ & $\begin{array}{c}0.116 \pm 0.003 \\
(66.08 \%)\end{array}$ & $\begin{array}{c}0.100 \pm 0.002 \\
(70.76 \%)\end{array}$ \\
\hline HI -BRK-ETH & $\begin{array}{c}0.196 \pm 0.004 \\
(42.69 \%) \\
\end{array}$ & $\begin{array}{c}0.171 \pm 0.001 \\
(50.00 \%)\end{array}$ & $\begin{array}{c}0.155 \pm 0.002 \\
(54.67 \%) \\
\end{array}$ & $\begin{array}{c}0.131 \pm 0.001 \\
(61.69 \%)\end{array}$ & $\begin{array}{c}0.120 \pm 0.002 \\
(64.91 \%)\end{array}$ \\
\hline HI -BRK-ACET & $\begin{array}{c}0.181 \pm 0.001 \\
(47.07 \%)\end{array}$ & $\begin{array}{c}0.165 \pm 0.002 \\
(51.75 \%)\end{array}$ & $\begin{array}{c}0.141 \pm 0.001 \\
(58.77 \%)\end{array}$ & $\begin{array}{c}0.120 \pm 0.002 \\
(64.91 \%)\end{array}$ & $\begin{array}{c}0.100 \pm 0.002 \\
(70.76 \%)\end{array}$ \\
\hline HI -BRK-WATE & $\begin{array}{c}0.181 \pm 0.001 \\
(40.35 \%)\end{array}$ & $\begin{array}{c}0.158 \pm 0.001 \\
(53.80 \%)\end{array}$ & $\begin{array}{c}0.138 \pm 0.004 \\
(59.64)\end{array}$ & $\begin{array}{c}0.116 \pm 0.003 \\
(66.08 \%)\end{array}$ & $\begin{array}{c}0.093 \pm 0.003 \\
(72.80 \%)\end{array}$ \\
\hline
\end{tabular}

\section{Acute Anti inflammatory Activity study:}

Following the up and down method, the ethanol, acetone and water extracts of leaves and bark of Holoptelia integrifolia at a dose of $300 \mathrm{mg} / \mathrm{kg}$ were selected in the present study. In Formalin-induced Inhibition of activity in mice, the inhibition percentage of the control, standard and test compounds are shown in Table V. The entire test compounds were compared with diclofenac as a standard at a concentration of $10 \mathrm{mg} / \mathrm{kg}$ for anti-inflammatory activity [17]. In this study, diclofenac showed $60.02 \%$ inhibition of inflammation at $3^{\text {rd }} \mathrm{h}$ when compared to control.
Ethanol, acetone and water extracts for leaves of Holoptelia integrifolia (300 mg/kg) showed significant inhibition of inflammation with 44.57\%, 36.55\% and 36.93\%, respectively (Table V). Whereas, $300 \mathrm{mg} / \mathrm{kg}$ Ethanol, acetone and water extracts for bark of Holoptelia integrifolia showed $42.57 \%, 31.73$ and $38.33 \%$ respectively inhibition of oedema, respectively at $3^{\text {rd }} \mathrm{h}$ when compared with control [18]. The results of test compounds were found to be statistically significant at value $* * * \mathrm{P}<0.001$, ** $\mathrm{P}<0.01$, * $\mathrm{P}<0.05$. 
Table V: Effect of $\mathrm{H}$. integrifolia plant extracts on formaline induced writhing in mice

\begin{tabular}{|l|l|c|c|}
\hline \multicolumn{1}{|c|}{ Groups } & \multicolumn{1}{|c|}{ Treatment } & $\begin{array}{c}\text { Mean no of writhing } \\
\pm \text { SEM }\end{array}$ & $\begin{array}{c}\text { \% Inhibition of } \\
\text { writhes }\end{array}$ \\
\hline Group-I & Saline & $40.50 \pm 1.25$ & - \\
\hline Group-II & Diclofenac $(10 \mathrm{mg} / \mathrm{Kg})$ & $15.59 \pm 0.92 * * *$ & $60.02 \%$ \\
\hline Group-III & Leaf-Ethanol $(300 \mathrm{mg} / \mathrm{Kg})$ & $23.00 \pm 1.06 * * *$ & $44.57 \%$ \\
\hline Group-IV & Leaf--Acetone $(300 \mathrm{mg} / \mathrm{Kg})$ & $25.33 \pm 1.38^{* * *}$ & $36.55 \%$ \\
\hline Group-V & Leaf--Water $(300 \mathrm{mg} / \mathrm{Kg})$ & $26.17 \pm 1.49^{* * *}$ & $36.93 \%$ \\
\hline Group-VI & Bark- Ethanol $(300 \mathrm{mg} / \mathrm{Kg})$ & $24.83 \pm 1.30^{* * *}$ & $42.57 \%$ \\
\hline Group-VII & Bark-Acetone $(300 \mathrm{mg} / \mathrm{Kg})$ & $28.33 \pm 1.66^{* * *}$ & $31.73 \%$ \\
\hline Group-VIII & Bark- Water $(300 \mathrm{mg} / \mathrm{Kg})$ & $23.59 \pm 1.43^{* * *}$ & $38.33 \%$ \\
\hline
\end{tabular}

Values are Mean \pm SEM ( $\mathrm{n}=6$ ) one way ANOVA followed by Dunnett's test. Where, $* * * \mathrm{P}<0.001, * * \mathrm{P}<0.01, * \mathrm{P}<0.05$ and ns represents Not significant.

\section{Chronic Anti inflammatory Activity study}

Following the up and down method, the ethanol, acetone and water extracts of leaves and bark of Holoptelia integrifolia at a concentration of $300 \mathrm{mg} / \mathrm{kg}$ were selected in the present study.

In Formalin-induced Paw Oedema activity in Albino wistar Rats, the paw volumes and percentage of inhibition of the control, standard and test compounds are shown in Table V. The entire test compounds were compared with diclofenac as a standard at a concentration of $100 \mathrm{mg} / \mathrm{kg}$ for antiinflammatory activity [19]. In this study, diclofenac showed $82.40 \%$ inhibition of inflammation at $5^{\text {th }} \mathrm{h}$ when compared to control.
Ethanol, acetone and water extracts for leaves of Holoptelia integrifolia (300 mg/Kg) showed significant inhibition of inflammation with 65.66\%, 20.60\% and 54.07\%, respectively (Table VI). Whereas, $300 \mathrm{mg} / \mathrm{Kg}$ Ethanol, acetone and water extracts for bark of Holoptelia integrifolia showed $59.22 \%, 28.75$ and $20.60 \%$ respectively inhibition of oedema, respectively at $5^{\text {th }} \mathrm{h}$ when compared with control [20]. The results of test compounds were found to be statistically significant at value $\mathrm{P}<0.05$.

Table VI: Effect of $\boldsymbol{H}$. integrifolia plant extracts on formalin-induced paw oedema (chronic) in rats

\begin{tabular}{|c|l|l|l|c|c|}
\hline Groups & \multicolumn{1}{|c|}{ Treatment } & $\begin{array}{c}\text { Initial Paw } \\
\text { Volume }\end{array}$ & $\begin{array}{c}\text { Paw } \\
\text { Volume after } \\
\text { Six Days }\end{array}$ & $\begin{array}{c}\text { Increase in } \\
\text { Paw Volume }\end{array}$ & $\begin{array}{c}\text { \% of } \\
\text { Inhibition }\end{array}$ \\
\hline Group-I & Saline & $1.28 \pm 0.07$ & $3.61 \pm 0.12$ & $2.33 \pm 0.06$ & - \\
\hline Group-II & Diclofenac $(10 \mathrm{mg} / \mathrm{Kg})$ & $1.23 \pm 0.04$ & $1.65 \pm 0.05$ & $0.41 \pm 0.07$ & $82.40 \%$ \\
\hline Group-III & Leaf-Ethanol $(300 \mathrm{mg} / \mathrm{Kg})$ & $1.26 \pm 0.03$ & $2.00 \pm 0.06$ & $0.80 \pm 0.12$ & $65.66 \%$ \\
\hline Group-IV & Leaf--Acetone $(300 \mathrm{mg} / \mathrm{Kg})$ & $1.21 \pm 0.06$ & $3.21 \pm 0.24$ & $1.85 \pm 0.16$ & $20.60 \%$ \\
\hline Group-V & Leaf--Water $(300 \mathrm{mg} / \mathrm{Kg})$ & $1.25 \pm 0.06$ & $2.25 \pm 0.16$ & $1.07 \pm 0.14$ & $54.07 \%$ \\
\hline Group-VI & Bark- Ethanol $(300 \mathrm{mg} / \mathrm{Kg})$ & $1.31 \pm 0.08$ & $2.26 \pm 0.10$ & $0.95 \pm 0.14$ & $59.22 \%$ \\
\hline Group-VII & Bark-Acetone $(300 \mathrm{mg} / \mathrm{Kg})$ & $1.23 \pm 0.06$ & $2.90 \pm 0.14$ & $1.66 \pm 0.17$ & $28.75 \%$ \\
\hline Group-VIII & Bark- Water $(300 \mathrm{mg} / \mathrm{Kg})$ & $1.26 \pm 0.06$ & $3.11 \pm 0.08$ & $1.85 \pm 0.11$ & $20.60 \%$ \\
\hline
\end{tabular}

Results are expressed on mean + SEM ( $n=6)$ from four observations of paw volume was measured after six days.

\section{CONCLUSION}

In the present work, the different extracts of leaves, bark and fruits of Holoptelia integrifolia was assessed for its antimicrobial, antioxidant and anti-inflammatory activity. The different extracts of Holoptelea integrifolia leaves, stem bark and fruits were determined as a potent natural source of antimicrobial, antioxidant and wound healing potential. The results of Antimicrobial activity of ethanol extract of leaves, bark and fruits for Holoptelia integrifolia shown excellent antibacterial activity against Bacillus subtilis, Pseudomonas aeruginosa, Micrococcus luteus, Eschericia coli and Proteus vulgaris but the antifungal activity shown against Asperigillus niger, Tricoderma vibriae and Chaetomium globosum. The results of Antioxidant activity of ethanol, acetone and water of leaves and bark for Holoptelia integrifolia have shown anti-oxidant activity at the at 250 $\mu \mathrm{g} / \mathrm{ml}$ concentration. Thus the present study concludes that the different extracts of leaves and bark of Holoptelia integrifolia have anti-inflammatory activity in acute and chronic phase of inflammation in laboratory animals at the dose of $300 \mathrm{mg} / \mathrm{kg}$ without ulcerogenic effect. Further investigation is needed to know the protective effect of leaves and bark of Holoptelia integrifolia using different animal models.

\section{ACKNOWLEDGMENT}

The authors express their sincere thanks to UGC-SERO for providing SERO/UGC-grant (MRP-4860/14) India, for providing the financial aid for this research work. We acknowledge Fr.T. Amal Arokia Raj, Principal of Loyola Degree College(YSRR), Pulivendula for their support and valuable help for the research work.

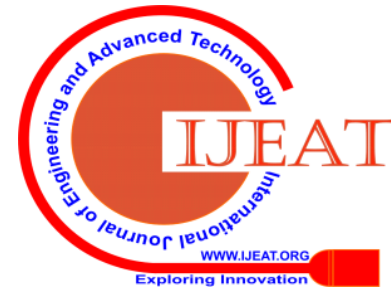




\section{CONFLICT OF INTEREST}

The authors confirmed that they do not have any conflict of interest.

\section{REFERENCES}

1. Chandrasekar, D., Madhusudhana, K., Ramakrishna, S. and Diwan P.V, "Evaluation of antimicrobial, antioxidant and wound-healing potentials of Holoptelea integrifolia”. J. Ethnopharmacol, 2008, 115, pp. 249- 256.

2. Perry, E.K., Pickering, A.T., Wang, W.W., Houghton, P.J., Perru, N.S, "Medicinal plants and Alzheimer's disease: from ethnobotany to phytotherapy" J. Pharm. Pharmacol., 1999, 51,pp. 527-534.

3. Lin, C.C., Huang, P.C, "Antioxidant and hepatoprotective effects of Acathopanax senticosus",Phytother. Res, 2002, 14, pp.489-494.

4. Yoon, J., Baek, S.J, " Molecular targets of dietary polyphenols with anti-inflammatory properties" Yonsei Med. J, 2006, 46, 585-596.

5. Sharma P.C, Yelne M.B, Dennis T.J. Database On Medicinal Plants Used In Ayurveda, " Central council for research in ayurveda \& siddha New Delhi, 2005, 2, 171-176.

6. Shrinivas S, Kale R, Mante A, Biyani K, "Ethanolic leaf extract of Holoptelia integrifolia Planch decreases cisplatin induced pica in rats" Pharmacognosy Magazine, 2008, 7, 293-297.

7. Huang, B., Ke, H.B., He, J.S., Ban, X.Q., Zeng, H., Wang, Y.W, "Extracts of Halenia elliptica exhibit antioxidant properties in vitro and in vivo" Food Chem. Toxicol, 2011, 49, 185-190.

8. Shon, M.Y., Kim, T.H., Sung, N.J, “Antioxidants and free radical scavenging activity of Phellinus baumii (Phellinus of Hymenochaetaceae) extracts” Food Chem, 2003, 82, 593-597.

9. Ruch, R.J., Cheng, S.J., Klaunig, J.E, "Prevention of cytotoxicity and inhibition of intracellular communication by antioxidant catechins isolated from Chinese green tea" J. Carcinog, 1983, 10, 1003-1008.

10. Perez, C., Paul, M. and Bazerque, P," An Antibiotic assay by the agar well diffusion method" Acta. Bio. Med. Exp. 1990, 15, 113-115.

11. Winter CA, Risley EA, Nuss GW, "Carrageenin induced oedema in hind paws of the rats as an assay of anti-inflammatory drugs" Proc Soc Exp Biol Med, 1962, 111:544-7. [PubMed: 14001233]

12. Asongalem EA, Foyet $\mathrm{H}$, Ekobo S, Dimo $\mathrm{T}$, Kamtchouing $\mathrm{P}$, "Anti-inflammatory, lack of central analgesia antipyretic properties of Acanthus montanus (Ness) T Anderson" J Ethnopharmacol. 2004, 95, 63-8. [PubMed: 15374608]

13. Daud A, Habib N, Riera S.," Anti-inflammatory, anti-nociceptive and antipyretic effects of extracts of Phrygilanthus acutifolius flowers" J Ethnopharmacol. 2006, 108, 198-203. [PubMed: 16797151]

14. P.Subramanyam,T.Mohammad Munawar and D.Muralidhar rao, "phytochemical analysis of some compounds from plant stem bark, lea and fruit extracts of holoptelia integrifolia" WJPR, 2017, Volume 6, Issue 10, 1070-1078.

15. Arora, D.S. and Bhardwaj, S.K, "Antibacterial activity of some medicinal plants" Geo. Bios. 1997, 24, 127-131.

16. Suresh, P.K., Sucheta, S., Sudarshana, V.D., Selvamani, P., Latha, S., "Antioxidant activity in some selected Indian medicinal plants." Afr. J. Biotech, 2008, 7, 1826-1828.

17. Panthong A, Kanjanapathi D, Taesotikul T, Wongcome T, Reutrakul "Anti-inflammatory and antipyretic properties of Clerodendrum petastites". Moore J Ethnopharmacol. 2003, 85, 151-6. [PubMed: 12576214].

18. Di Rosa M, Giroud JP, Willoughby DA. "Studies of the mediators of the acute inflammatory response induced in rats in different sites by carrageenin and turpentine" J Pathol. 1971, 04:15-29. [PubMed: 4398139]

19. Rajeswari R, Thejomoorthy P, Mathuram LN, Narayana Raju KV" Anti-inflammatory activity of Cassia fistula Linn.Bark extracts in sub-acute model of inflammation in rats" Tamil J Vet Anim Sci. 2006, 2, 193-9.

20. 20. anthong A, Kanjanapathi D, Taesotikul T, Pankummoon A, Panthong K, Reutrakul V" Anti-inflammatory activity of methanolic extracts from Ventilago harmandiana Pierre" J Ethnopharmacol. 2004, 91, 237-42.

\section{AUTHORS PROFILE}

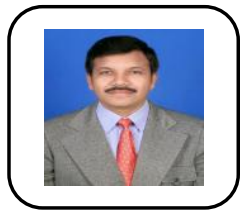

Dr. P. Subramanyam He is the lecturer in the Department of Botany at Loyola Degree College, Pulivendula, Andhra Pradesh, India. His area of research is photochemical screening, evaluation of antioxidant, antimicrobial and anti-inflammatory of plant parts. He published 08 research papers in reputed journals like UGC and Scopus Indexed. Also nearly 10 papers contribution in national and international conferences. He invited as a guest lecturer in government and reputed degree colleges.

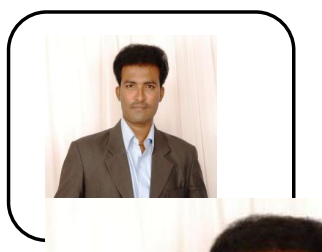

Dr.T.Mohammad Munawar $\mathrm{He}$ is the Assistant Professor in the Department of BCEN at Mekelle Institute of Technology (MIT), Mekelle University, Mekelle, Ethiopia. His area of interest is Biochemical Engineering, Fermentation technology, Bionanotechnology and Biofuels . He published 28 research papers reputed journals like UGC, Scopus Indexed and SCI. Also nearly 14 papers contribution in national and international conferences. He invited as a guest lecturer in government and reputed Engineering colleges. He is an Member of The Institution of Engineers, a life member of ISTE, Member of Indian science congress of Association and member of All Indian Biotechnologist Association.

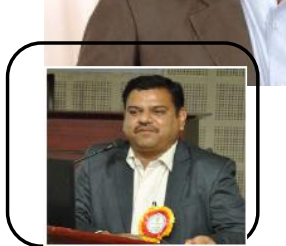

r. D, Muralidhar Rao He is the Assistant the Department of Biotechnology, S.K University, Anantapuramu, Andhra Pradesh, India. His area of research is Bioprocess Engineering, Medicinal plants, Industrial Biotechnology and Fermentation Technology . He published 125 research papers in renowed journals lik Scopus Indexed Pubmed and SCI. Also nearly 25 papers contribution in national and international conferences. He is an Member of The Indian science congress of Association, a Member of Society for Applied Biotechnology and BRSI, India.

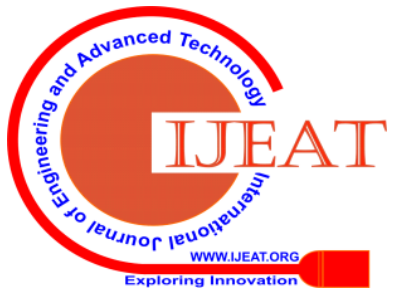

